\title{
Slavica Čepon*
}

\author{
Faculty of Economics \\ University of Ljubljana, Slovenia \\ slavica.cepon@ef.uni-lj.si
}

\section{TEACHERS' AND STUDENTS' PERSPECTIVES ON THE REASONS FOR SPEAKING ANXIETY IN ENGLISH FOR SPECIFIC PURPOSES}

\section{Abstract}

The goal of this quantitative study is to fill the research gap and determine the teachers' and students' perceptions of the reasons for speaking anxiety in English for specific purposes (ESP). A survey was carried out with 335 students and 24 teachers of ESP from 18 Slovenian higher educational institutions responding to a purposely constructed questionnaire. ESP students emphasized a lack of the knowledge of the carrier content in English and their mother tongue, whereas the teachers stated that oral tests, failing to speak fluently and concern about being looked down upon for making mistakes in real and carrier content are crucial causes of ESP students' speaking anxiety. A lack of the knowledge of the carrier content is an important reason for speaking anxiety that language teachers in ESP are not aware of to a sufficient extent.

\section{Key words}

English for specific purposes, speaking anxiety, carrier content, real content, students' and teachers' perspectives.

\footnotetext{
* Corresponding address: Slavica Čepon, University of Ljubljana, Faculty of Economics, Department of Languages for Business and Economics, Kardeljeva ploščad 17, 1000 Ljubljana, Slovenia.
} 


\section{Sažetak}

Cilj ove kvantitativne studije je da popuni prazninu u istraživanju i utvrdi shvatanja nastavnika i studenata o razlozima govorne anksioznosti u okviru nastave engleskog jezika nauke i struke (EJNS). Istraživanje je sprovedeno pomoću posebno osmišljenog upitnika na uzorku od 335 studenata i 24 nastavnika EJNS sa 18 visokoškolskih institucija u Sloveniji. Studenti EJNS su kao razlog govorne anksioznosti istakli nedostatak znanja iz matične oblasti struke, kako na engleskom tako i na maternjem jeziku, dok su za nastavnike osnovni razlozi usmeni način ispitivanja, nesposobnost tečnog govora, kao i zabrinutost zbog potcenjivanja usled mogućih grešaka, kako jezičkih tako i onih na području matične oblasti struke. Nedostatak znanja iz matične oblasti struke važan je razlog govorne anksioznosti za studente EJNS, kojeg nastavnici EJNS struke nisu dovoljno svesni.

\section{Ključne reči}

engleski jezik nauke i struke, govorna anksioznost, matična oblast struke, jezička kompetencija kao stvarni sadržaj, shvatanja nastavnika i studenata.

\section{INTRODUCTION}

There is a consensus among foreign language scholars (e.g. Horwitz, 2001; Horwitz, Horwitz, \& Cope, 1986; MacIntyre \& Gardner, 1994; Yan Xiu \& Horwitz, 2008; Young, 1990) that anxiety is one of the key factors affecting the learning of a foreign language (FL). Although Dörnyei (2005) stresses that FL anxiety is still not clearly defined and is too often equated with other fears or phobias, it can be broadly defined as the feeling of tension and apprehension occurring when learners have to perform tasks (speaking, writing, reading and listening) in an FL in which they are not proficient (MacIntyre \& Gardner, 1994).

This study focuses on speaking anxiety in English since English is the most common FL in the EU. In 2012 (Johnson, 2016) a report found that 38\% of the EU's citizens and nearly all of those working at EU institutions in Brussels speak English. Even before the UK referendum turnout in 2016, it was expected that the institutions of the EU would continue speaking English should Britain leave the EU (Johnson, 2016).

Several studies confirm that the speaking skill in English and in many other foreign languages could be the most intimidating aspect of foreign language learning since a competent speaker must synthesize a variety of skills to speak 
sufficiently well (Horwitz, Horwitz, \& Cope, 1991; Öztürk \& Gürbüz, 2014; Price, 1991; Young, 1990). Some studies (e.g. Çagatay, 2015; Heng, Abdullah, \& Yosaf, 2012) have revealed that English students may undergo a moderate level of English speaking anxiety; however, even a moderate level is alarming because it might discourage students from expressing their thoughts in English, affect their willingness to communicate ( $\mathrm{Wu} \& \mathrm{Lin}, 2014)$ and hinder the development of communicative competence in the long run (Çagatay, 2015).

Although individual reasons for speaking anxiety in English (such as not being familiar with the target language, lack of self-confidence and being afraid of making mistakes) are more dominant than others, generally speaking, the reasons for speaking anxiety are also environmental and educational, not strictly individual. According to some studies, most students worry about making pronunciation and vocabulary mistakes while speaking in the classroom (Horwitz et al., 1986; Koch \& Terrell, 1991; Öztürk \& Gürbüz, 2014; Price, 1991). Potential reactions and evaluations by other students in class can be a dominant factor in regard to the anxiety that students experience while speaking, since students may become more anxious about making mistakes in pronunciation and fear being laughed at when they speak without being prepared in advance and when exposed to immediate questions (Öztürk \& Gürbüz, 2014).

Students and teachers have different perspectives on speaking anxiety in English, as confirmed by He (2013) in the only study comparing teachers' and students' perspectives regarding the reasons for general English speaking anxiety. On the basis of comprehensive data from 332 participants (302 students and 30 teachers) at two universities in China, He (2013) identified 13 major reasons for Chinese students' English speaking anxiety. Only two among the five least supported reasons by both the students and teachers are the same, namely "fear of speaking English relative to reading and writing in it" and "fear of speaking English with others". Data also indicate that a lack of vocabulary is the most important reason according to students, whereas teachers attached significantly less importance to this reason. The different views about the reasons for speaking anxiety in an FL between students and teachers call for a mutual understanding and communication so that everybody can be better informed of each other's viewpoints.

Current studies on the reasons for English speaking anxiety have been focused on English for general purposes (e.g. Boyce, Alber-Morgan, \& Riley, 2007; He, 2013; Subașl, 2010; Zhang \& Zhong, 2012) and have neglected ESP, although ESP teaching/learning differs from English for general purposes (Hyland, 2002, 2008). The specificity of ESP led us to assume that also the reasons leading to speaking anxiety in ESP (but identified by expert literature for general English) would be different from those encountered by a target group of general English students (He, 2013; Zhang \& Zhong, 2012). Moreover, we also expected that the views of ESP teachers on the reasons for speaking anxiety in ESP would also comply with the views of ESP students, but at the same time would be significantly 
different from the reasons identified by expert literature for general English (He, 2013). Since there is a gap in research carried out into the differences between the students' and teachers' perspectives on the reasons for speaking anxiety in ESP, and since the first step in reducing students' speaking anxiety is knowing how the main actors of the learning process perceive reasons for students' speaking anxiety, the goal of this quantitative study was to determine the differences between the students' and teachers' perspectives on the reasons for speaking anxiety of Slovenian university ESP students. A survey was carried out with 335 students and 24 teachers of ESP from 18 Slovenian higher educational institutions.

\section{REASONS FOR SPEAKING ANXIETY IN ENGLISH FOR SPECIFIC PURPOSES}

The question of the importance of the speaking skill for ESP learners is inescapably implicated in the debate involving the issue of speaking anxiety in ESP. In practice, mastering the speaking skill may not be more important for ESP learners than mastering other FL macro skills. On the other hand, incorporating micro speaking skills into ESP instruction (e.g. reporting, negotiating, attending meetings, clarifying, problem solving, etc.) is deemed critical for building adult workforce readiness skills in an FL (Grognet, 1997). In fact, ESP instruction normally resorts to promoting the integration of all four FL macro skills and does not use specific work-related learning materials and target discourse samples (Čepon, 2012), because of the range and variety of professional positions potentially available to ESP students in the future, worldwide and in students' homelands, which is so diverse that it is practically undefinable. Due to this, it is not possible to operationally define either all future work-oriented FL macro and micro skills or FL communication skills for such a variety of different job tasks.

The answer to the question about the difference between speaking anxiety in ESP and in general English may be hidden in the claim that the difference between general English and ESP is supposedly "in theory nothing, in practice a great deal" (Hutchinson \& Waters, 1987: 53). Essentially, there are quite a few differences as well as similarities between ESP and general English, thus the demarcation line is fine (Ellis \& Johnson, 1994). The common thread of all conceptualizations of ESP has been the specificity of ESP, since ESP was clearly meant to be different from general English (Hyland, 2002, 2008; Zhu, 2008), intended for advanced learners and centred on the language, skills, discourse and genres appropriate for particular disciplines, occupations and activities (Dudley-Evans \& St. John, 1998; Gatehouse, 2001). General English is less specific and less purpose-oriented than ESP, as the latter is a needs-directed teaching in which as much as possible must be made jobrelated, focused on learners' needs, relevant to them (Widdowson, 1984). The most crucial difference arises from the fact that ESP instruction deals with two types of content, namely the real content - the English language - and the carrier 
content, the specialist subject matter relating to a certain discipline. The consensus in ESP is that the carrier content is only a framework through which the real content of English is to be brought out. The essence of ESP is always learning an FL and not the specialist subject matter.

Despite the fact that that the complexity of ESP contents undeniably makes ESP instruction different from general English instruction only one study so far has examined the issue of speaking anxiety of ESP students. The study by Čepon (in press) classified the causes of speaking anxiety in ESP as major/minor and as latent/evident from the ESP learners' viewpoint since the causes are always conspicuous to ESP teachers. Apparently, the two major evident causes are insufficient carrier content in ESP and insufficient real content of ESP instruction i.e., general English competence. The two major latent causes are ESP learners' poor L1 linguistic skills (especially L1 grammar skills) as well as the inability to differentiate between FL production and reception. Minor causes arising from ESP learners are: a lack of conceptual fluency of L1 as well as metaphorical competence of L1 in an FL, perceiving ESP classroom discussion to be a form of verbal testing rather than constructing knowledge, a lack of vocabulary relating to ESP disciplines, ESP learners' preoccupation with pronunciation and accuracy rather than fluency, fear of negative evaluation by ESP teachers and peers, unrealistically high aspirations of non-native speakers in an FL, inability to differentiate between facilitating and debilitating speaking anxiety, competitive nature of BE learners (e.g. resentment of less proficient ESP learners), more proficient ESP learners as instigators of speaking anxiety and the level of perceived support from ESP teachers. Minor causes arising from ESP teachers are ESP teachers' intolerance of silence on the part of ESP learners, ESP teachers' preconceived beliefs about FL learning and ESP teachers' manner of error correction.

The in-depth interviews (Čepon, in press) also indicated that the causes of speaking anxiety in ESP were very different from the ones in general English and that ESP instruction does induce additional levels of speaking anxiety. In other words, speaking anxiety in general English arises mainly from the learners' insufficient English language competence. The other two major latent causes for speaking anxiety in general English are the same as in ESP, namely poor L1 linguistic skills and the inability of learners to differentiate between FL production and reception.

Moreover, the study results showed that there is no direct rectilinear connection between the carrier content in non-native speakers' mother tongues and an FL, or between their English language competence and speaking anxiety. High-anxiety learners are not automatically less proficient, just as more proficient learners are not necessarily low-anxiety. Namely, with non-native learners of English the relationship between high- and low-anxiety on the one hand and more and less proficient in an FL on the other hand appears to be additionally complicated by one of the pre-requisites of ESP - the knowledge of the carrier content in both their mother tongue and English or a lack of it. The in-depth 
interviews showed that a relatively good knowledge of the carrier content in Slovenian is no guarantee of equally good knowledge of the carrier content in English or low levels of speaking anxiety in English.

The study results (Čepon, in press) also confirmed that subject-matter differences among various ESP disciplines do not significantly impact the levels of ESP learners' speaking anxiety since ESP instruction must always attempt to put as much emphasis as possible on ESP learners' general ability to communicate effectively in an FL in the future, and not on very specific ESP carrier content, whether it be economics, logistics or any other ESP discipline. The fact that ESP instruction has to balance carrier content level (sometimes quite specialized) and language level, and at the same time focus on the language, appears to neutralize the subject-matter differences among various ESP disciplines (Johns \& PriceMachado, 2001).

\section{METHODOLOGY}

\subsection{Study design and participants}

The study design was a cross-sectional questionnaire survey seeking an answer to the following research questions:

RQ1: What kind of perspectives on the reasons for speaking anxiety do ESP students and their teachers have?

RQ2: Are there are any differences between ESP students' and their teachers' perspectives on the reasons for speaking anxiety in ESP?

A total of 359 participants (335 students and 24 teachers) from eighteen faculties from all four Slovenian universities, namely the University of Ljubljana, the University of Maribor, the University of Nova Gorica and the University of Primorska took part in the questionnaire survey in the 2016 winter and spring semesters. The inclusion of ESP teachers and students was considered necessary to ensure independent, possibly differing, perspectives on the same issue of speaking anxiety. ESP teachers and students were selected as the participants because they are the most deeply involved in the daily teaching and learning of ESP and thus most closely related to the issues addressed in this study. ESP teachers at Slovenian faculties were sent an invitation to participate in the study and to invite their students to fill out an e-survey. Among ESP teachers, 22 were female and 2 male, aged from 30 to 60 , with between 7 and 30 years of teaching experience, who have all been awarded the habilitation required for ESP teachers at the tertiary level in Slovenia. 
The study included 224 female and 111 male students, aged between 18 and 24 , in the first or second year at various faculties (but studying ESP for the first time), who on enrolment had to fulfil the B1/B2 English language requirements. The carrier content of their ESP study involves various disciplines, such as economics, business, and management ( $\mathrm{N}=62,15$ male, 47 female), tourism $(\mathrm{N}=52$, 14 male, 38 female), maritime studies ( $\mathrm{N}=51,30$ male, 21 female), political studies $(\mathrm{N}=34,11$ male, 23 female), sociology ( $\mathrm{N}=31,10$ male, 21 female), communication studies and journalism ( $\mathrm{N}=26,8$ male, 18 female), law ( $\mathrm{N}=22,7$ male, 15 female), medicine ( $\mathrm{N}=19,7$ male, 12 female), logistics ( $\mathrm{N}=14,4$ male, 10 female), transport $(\mathrm{N}=12,3$ male, 9 female), pedagogics and anthropology ( $\mathrm{N}=12,2$ male, 10 female).

\subsection{Data collection instruments}

For the purpose of this study, we adopted a 5-point Likert scale for The Foreign Language Speaking Anxiety Scale (He, 2013) for ESP (see Table 1). To adapt a 13item questionnaire (He, 2013) to the specifics and complexity of ESP, four new items $(4,10,16$ and 17) were added based on Čepon's (in press) findings on important reasons for students' business English speaking anxiety. The final version of the questionnaire contains 17 structured items.

\footnotetext{
1. I feel embarrassed to speak ESP, because I think my pronunciation and intonation are poor.

2. I am often worried that if I cannot speak ESP well, I will not get a decent job in future.

3. I feel that not knowing enough vocabulary is the biggest problem preventing me from speaking ESP easily.

4. A lack of knowledge of my academic discipline is preventing me from speaking ESP.

5. I become anxious when I get stuck on one or two words in speaking ESP.

6. I feel more nervous when having to give important information orally in ESP.

7. I would not be so anxious just to learn to read and write in ESP rather than having to learn to speak as well.

8. I do not mind thinking aloud in ESP, but I feel very uncomfortable when I have to speak to others in it.

9. I am nervous if I have to speak ESP when I am not familiar with the topic.

10. I get anxious when I have to discuss my academic discipline in general, because I have not mastered it yet.

11. When speaking ESP, I often know all the words I need, but still fail to express myself easily due to anxiety.

12. I feel nervous when having to be tested orally in ESP.

13. I get worried when I have little time to think about what I have to talk about in ESP.

14. I get anxious when I find I cannot speak in ESP fluently.

15. Others will look down on me if I make mistakes in speaking ESP.

16. I get anxious when I have to react unprepared to a group interaction on topics from my academic discipline.

17. I feel nervous or get anxious when I have to carry out complex professional speaking activities based on the knowledge of my academic discipline.
}

Table 1. Speaking anxiety scale items for ESP (adapted from He, 2013)

To ensure optimal comprehensibility, the ESP anxiety scale was translated into the Slovenian language. The reliability of the scale was estimated by assessing the 
internal consistency of the scale using Cronbach's Alpha, which demonstrates positive results $(\alpha=0.86)$.

In order to enable the teachers to judge their students' anxiety levels and feelings as an independent stakeholder, a teacher's version of the questionnaire was provided. The two versions are almost the same except for some wording, since teaching and learning are two aspects of the research questions. For example, the item "I feel nervous or get anxious when I have to carry out complex professional speaking activities based on the knowledge of my academic discipline." was for the teachers reworded as "Students feel nervous or get anxious when they have to carry out complex professional speaking activities based on the knowledge of their academic discipline." The last part of the questionnaire focused on demographics, including age, gender, and faculty.

\subsection{Analysis}

After the main questionnaire data were collected, the response frequencies and the means of all the items were tabulated. Rank-orders of the means for both student and teacher groups were obtained to examine the importance of the reasons to each group. Multivariate analysis of variance (MANOVA) was also conducted to find specific differences in the emphasis of the reasons between student and teacher groups. ${ }^{1}$ This method compared the two groups (students and teachers) in terms of their means on each of the 17 items.

\section{RESULTS}

Table 2 and Table 3 show the rank orders of the items in line with decreasing order of means. Table 2 shows that the students defined as the most important reasons for ESP speaking anxiety a lack of knowledge of the topic (item 9) and academic discipline (item 10). This suggests that for the students a key reason for ESP speaking anxiety is a lack of the specialist carrier content. According to the students, among the top reasons for ESP speaking anxiety are also unprepared speaking (item 16) and performance of complex professional speaking activities based on the knowledge of the academic discipline (item 17). Four reasons had a 3.7 mean score: speaking ESP (item 7), speaking to others in ESP (item 8), oral test (item 12) and too little time to prepare for speaking (item 13). Giving important information orally (item 6) had a 3.6 mean score. Five reasons had a 3.5 mean

\footnotetext{
${ }^{1}$ Multivariate analysis of variance is one of the most common multivariate statistical procedures in the social science literature. MANOVA is a member of the General Linear Model - a family of statistical procedures that are often used to quantify the strength between variables (Zientek \& Thompson, 2009). MANOVA, specifically, is an analysis of variance (ANOVA) that has two or more dependent variables (Fish, 1988).
} 
score: poor pronunciation and intonation (item 1), a concern about not getting a decent job in future without knowing how to speak well (item 2), not knowing enough ESP vocabulary (item 3), a lack of knowledge of the academic discipline (item 4) and pressure from the peer group (item 15). At the end of the list, there are three reasons with 3.4 mean score, which dealt with English language proficiency: getting stuck on one or two words (item 5), inability to speak fluently (item 14) and to express oneself easily (item 11).

\begin{tabular}{|c|c|c|c|c|c|c|}
\hline ITEMS & SD (\%) & $D(\%)$ & $N(\%)$ & $A(\%)$ & $S A(\%)$ & MEAN \\
\hline $\begin{array}{l}\text { 9. I am nervous if I have to speak ESP when I am not } \\
\text { familiar with the topic. }\end{array}$ & 3.9 & 9.9 & 17.6 & 40.0 & 28.7 & 3.9 \\
\hline $\begin{array}{l}\text { 10. I get anxious when I have to discuss my academic } \\
\text { discipline in general, because I have not mastered it yet. }\end{array}$ & 6.0 & 11.9 & 16.7 & 39.1 & 26.3 & 3.9 \\
\hline $\begin{array}{l}\text { 16. I get anxious when I have to react unprepared to a } \\
\text { group interaction on topics from my academic discipline }\end{array}$ & 12.2 & 20.0 & 21.8 & 33.4 & 12.5 & 3.8 \\
\hline $\begin{array}{l}\text { 17. I feel nervous or get anxious when I have to carry } \\
\text { out complex professional speaking activities based on } \\
\text { the knowledge of my academic discipline. }\end{array}$ & 7.8 & 14.3 & 17.6 & 39.4 & 20.9 & 3.8 \\
\hline $\begin{array}{l}\text { 7. I would not be so anxious just to learn to read and } \\
\text { write in ESP rather than having to speak as well. }\end{array}$ & 11.6 & 15.5 & 17.0 & 31.9 & 23.9 & 3.7 \\
\hline $\begin{array}{l}\text { 8. I do not mind thinking aloud in ESP, but I feel very } \\
\text { uncomfortable when I have to speak to others in it. }\end{array}$ & 10.7 & 17.0 & 19.1 & 32.5 & 20.6 & 3.7 \\
\hline 12. I feel nervous when having to be tested orally in ESP. & 13.4 & 18.5 & 22.1 & 25.4 & 20.6 & 3.7 \\
\hline $\begin{array}{l}\text { 13. I get worried when I have little time to think about } \\
\text { what I have to talk about in ESP. }\end{array}$ & 10.4 & 13.4 & 20.6 & 37.0 & 18.5 & 3.7 \\
\hline $\begin{array}{l}\text { 6. I feel more nervous when having to give important } \\
\text { information orally in ESP. }\end{array}$ & 12.8 & 20.3 & 17.0 & 29.9 & 20.0 & 3.6 \\
\hline $\begin{array}{l}\text { 1. I feel embarrassed to speak ESP, because I think my } \\
\text { pronunciation and intonation are poor. }\end{array}$ & 15.5 & 23.3 & 22.1 & 24.5 & 14.6 & 3.5 \\
\hline $\begin{array}{l}\text { 2. I am often worried that if I cannot speak ESP well I } \\
\text { will not get a decent job in future. }\end{array}$ & 13.1 & 27.2 & 19.7 & 29.9 & 10.1 & 3.5 \\
\hline $\begin{array}{l}\text { 3. I feel that not knowing enough vocabulary is the } \\
\text { biggest problem preventing me from speaking } \\
\text { ESP easily. }\end{array}$ & 12.2 & 21.2 & 21.5 & 32.5 & 12.5 & 3.5 \\
\hline $\begin{array}{l}\text { 4. A lack of knowledge of my academic discipline is } \\
\text { preventing me from speaking ESP. }\end{array}$ & 7.8 & 29.0 & 33.4 & 24.2 & 5.7 & 3.5 \\
\hline $\begin{array}{l}\text { 15. Others will look down on me if I make mistakes } \\
\text { speaking ESP. }\end{array}$ & 16.7 & 22.7 & 19.4 & 26.9 & 14.3 & 3.5 \\
\hline $\begin{array}{l}\text { 5. I become anxious when I get stuck on one or two } \\
\text { words when speaking ESP. }\end{array}$ & 17.6 & 21.5 & 20.0 & 27.5 & 13.4 & 3.4 \\
\hline $\begin{array}{l}\text { 14. I get anxious when I find I cannot speak in ESP } \\
\text { fluently. }\end{array}$ & 11.3 & 17.6 & 20.6 & 29.6 & 20.9 & 3.4 \\
\hline $\begin{array}{l}\text { 11. When speaking ESP, I often know all the words I } \\
\text { need, but still fail to express myself easily due to anxiety. }\end{array}$ & 16.1 & 26.3 & 20.6 & 24.8 & 12.2 & 3.4 \\
\hline
\end{tabular}

Note: SD-strongly disagree; D-disagree; N-neither agree nor disagree; A-agree; SA- strongly agree.

Table 2. Frequencies and means for ESP anxiety scale items for the students' perceptions of the reasons for ESP speaking anxiety $(\mathrm{N}=335)$

Table 3 shows that the top seven reasons for speaking anxiety observed by the ESP teachers were: oral test (item 12), students cannot speak ESP fluently (item 14), pressure from the peer group (item 15), giving important information orally (item 
6), speaking to others in ESP (item 8), being unfamiliar with the topic (item 9), performance of complex professional speaking activities (item 17). In the middle of the list are the following reasons: too little time (item 13) and a lack of knowledge of the academic discipline (item 10) with a 3.9 mean score, speaking unprepared in ESP (item 16) with a 3.8 mean score, speaking as the most difficult skill in ESP (item 7) with a 3.7 mean score, poor pronunciation and intonation (item 1) with a 3.6 mean score, inability to express themselves in an FL easily (item 11) and not knowing enough vocabulary (item 3) with a 3.5 mean score. At the end of the list, there are three reasons for speaking anxiety in ESP with the lowest frequency: getting stuck on one or two words (item 5) with a 3.3 mean score, a concern about not getting a decent job in future without speaking ESP well (item 2) with a 2.9 mean score, and a lack of the knowledge of an academic discipline (item 4) with a 2.8 mean score.

\begin{tabular}{|c|c|c|c|c|c|c|}
\hline ITEMS & SD (\%) & $D(\%)$ & $N(\%)$ & $A(\%)$ & $S A(\%)$ & MEAN \\
\hline 12. Students feel nervous when having to be tested orally in ESP. & & & 16.7 & 45.8 & 37.5 & 4.2 \\
\hline $\begin{array}{l}\text { 14. Students get anxious when they find they cannot speak in } \\
\text { ESP fluently. }\end{array}$ & & & 12.5 & 66.7 & 20.8 & 4.1 \\
\hline $\begin{array}{l}\text { 15. Students think others will look down on them if they make } \\
\text { mistakes speaking ESP. }\end{array}$ & & 4.2 & 16.7 & 45.8 & 33.3 & 4.1 \\
\hline $\begin{array}{l}\text { 6. Students feel more nervous when having to give important } \\
\text { information orally in ESP. }\end{array}$ & & 4.2 & 33.3 & 20.8 & 41.7 & 4.0 \\
\hline $\begin{array}{l}\text { 8. Students do not mind thinking aloud in ESP, but they feel } \\
\text { very uncomfortable when they have to speak to others. }\end{array}$ & & 20.8 & 58.3 & 20.8 & & 4.0 \\
\hline $\begin{array}{l}\text { 9. Students are nervous if they have to speak ESP when they } \\
\text { are not familiar with the topic. }\end{array}$ & 4.2 & 4.2 & 8.3 & 50.0 & 33.3 & 4.0 \\
\hline $\begin{array}{l}\text { 17. Students feel nervous or get anxious when they have to } \\
\text { carry out complex professional speaking activities based on } \\
\text { the knowledge of their academic discipline. }\end{array}$ & & 4.2 & 16.7 & 58.3 & 20.8 & 4.0 \\
\hline $\begin{array}{l}\text { 13. Students get worried when they have little time to think } \\
\text { about what they have to discuss in ESP. }\end{array}$ & & & 20.8 & 66.7 & 12.5 & 3.9 \\
\hline $\begin{array}{l}\text { 10. Students get anxious when they have to discuss their academic } \\
\text { discipline in general, because they have not mastered it yet. }\end{array}$ & 4.2 & 8.3 & 4.2 & 62.5 & 20.8 & 3.9 \\
\hline $\begin{array}{l}\text { 16. Students get anxious when they have to react unprepared } \\
\text { to a group interaction on topics from the academic discipline. }\end{array}$ & & 4.2 & 29.2 & 54.2 & 12.5 & 3.8 \\
\hline $\begin{array}{l}\text { 7. Students would not be so anxious just to learn to read and } \\
\text { write in ESP rather than having to learn to speak as well. }\end{array}$ & 4.2 & 8.3 & 20.8 & 45.8 & 20.8 & 3.7 \\
\hline $\begin{array}{l}\text { 1. Students feel embarrassed to speak ESP, because they think } \\
\text { their pronunciation and intonation are poor. }\end{array}$ & 4.2 & 8.3 & 25.0 & 45.8 & 16.7 & 3.6 \\
\hline $\begin{array}{l}\text { 11. When speaking ESP, students often know all the words } \\
\text { they need, but still fail to express themselves easily due to } \\
\text { anxiety. }\end{array}$ & 4.2 & 8.3 & 29.2 & 50.0 & 8.3 & 3.5 \\
\hline $\begin{array}{l}\text { 3. Students feel that not knowing enough vocabulary is the } \\
\text { biggest problem preventing them from speaking ESP easily. }\end{array}$ & & 8.3 & 33.3 & 54.2 & 4.2 & 3.5 \\
\hline $\begin{array}{l}\text { 5. Students become anxious when they get stuck on one or two } \\
\text { words in speaking ESP. }\end{array}$ & & 25.0 & 25.0 & 50.0 & & 3.3 \\
\hline $\begin{array}{l}\text { 2. Students are often worried that if they cannot speak ESP } \\
\text { well, they will not get a decent job in future. }\end{array}$ & 4.2 & 37.5 & 29.2 & 20.8 & 8.3 & 2.9 \\
\hline $\begin{array}{l}\text { 4. Students think that a lack of knowledge of their academic } \\
\text { discipline is preventing them from speaking ESP. }\end{array}$ & 8.3 & 29.2 & 41.7 & 16.7 & 4.2 & 2.8 \\
\hline
\end{tabular}

Table 3. Teachers' response frequencies and means of the speaking anxiety scale items for ESP $(\mathrm{N}=24)$ 
Table 4 shows that MANOVA at item level revealed significant differences on nine (items $2,4,6,8,12,13,14,15$, and 17) out of the 17 items between students and teachers. The calculations of items $1,3,4,5,7,9,10,11$, and 16 did not show significant differences between students and teachers.

\begin{tabular}{|c|c|c|}
\hline ITEMS & \multicolumn{2}{|c|}{ MEAN } \\
\hline & Ss $/ T s$ & Differences \\
\hline $\begin{array}{l}\text { 2. Students are often worried that if they cannot speak ESP well, } \\
\text { they will not get a decent job in future. }\end{array}$ & $3.5 / 2.9$ & $.6 * *$ \\
\hline $\begin{array}{l}\text { 4. Students think that a lack of knowledge of their academic } \\
\text { discipline is preventing them from speaking ESP. }\end{array}$ & $3.5 / 2.8$ & $.7^{* * *}$ \\
\hline $\begin{array}{l}\text { 6. Students feel more nervous when having to give important } \\
\text { information orally in ESP. }\end{array}$ & $3.6 / 4.0$ & $-.4^{*}$ \\
\hline $\begin{array}{l}\text { 8. Students do not mind thinking aloud in ESP, but they feel very } \\
\text { uncomfortable when they have to speak to others in it. }\end{array}$ & $3.7 / 4.0$ & $-.3^{*}$ \\
\hline 12. Students feel nervous when having to be tested orally in ESP. & $3.7 / 4.2$ & $-.5^{* *}$ \\
\hline $\begin{array}{l}\text { 13. Students get worried when they have little time to think about } \\
\text { what they have to discuss in ESP. }\end{array}$ & $3.7 / 3.9$ & $-.2 *$ \\
\hline $\begin{array}{l}\text { 14. Students get anxious when they find they cannot speak in ESP } \\
\text { fluently. }\end{array}$ & $3.4 / 4.1$ & $-.7^{* *}$ \\
\hline $\begin{array}{l}\text { 15. Students think others will look down on them if they make } \\
\text { mistakes in speaking ESP. }\end{array}$ & $3.5 / 3.8$ & $-.3 *$ \\
\hline $\begin{array}{l}\text { 17. Students feel nervous or get anxious when they have to carry } \\
\text { out complex professional speaking activities based on the } \\
\text { knowledge of their academic discipline. }\end{array}$ & $3.8 / 4.0$ & $-.2 *$ \\
\hline
\end{tabular}

Table 4. Means and difference of item scores on which students and teachers showed significant differences $(\mathrm{N}=359)$

Table 4 also shows that teachers scored significantly higher than students on seven items. Among them, four reasons (items 6, 8, 13 and 14) are related to the situation in which students have to speak quickly and fluently to others, presenting important information in ESP. The teachers placed significantly more emphasis than students on an oral test (item 12) and situations when students have to carry out complex professional speaking activities based on the knowledge of an academic discipline (item 17). Significantly higher mean scores on these items indicate that teachers were more likely than students to regard these reasons as important regarding speaking anxiety in ESP. Students emphasized more than their ESP teachers a worry about not getting a decent job in future without speaking ESP well (item 2). Students also scored significantly higher on the reason for the lack of the knowledge of an academic discipline (item 4). 


\section{DISCUSSION}

If we compare our findings with the research so far that measures speaking anxiety in English for general purposes (e.g. He, 2013), we can conclude that there are no significant differences in the perception of the reasons for speaking anxiety. For instance, He (2013) found that speaking on an unfamiliar topic was a very prominent reason for speaking anxiety in general English. This cause was also strongly emphasized by both ESP students and teachers in our study. However, in comparison with English for general purposes, the academic knowledge of the carrier content is crucial for ESP instruction where the presentation of certain language items (real content) in all foreign language skills should rely on the topics from some discipline (carrier content) (Dudley-Evans \& St. John, 1998).

The results of this study point towards insufficient knowledge of the carrier content, both in the mother tongue and English, as the key reason for preexperience ESP students' speaking anxiety: the necessity to discuss the carrier content in English before having really mastered it in their mother tongue, speaking on unfamiliar topics in English, speaking unprepared in ESP about the topics from the academic discipline and carrying out complex professional speaking activities based on the knowledge of the academic discipline. The teachers' perspective is that being tested orally in ESP, not speaking ESP fluently and social pressures from a peer group are the most serious causes of students' speaking anxiety in ESP. In other words, ESP teachers are not of the opinion that a lack of the knowledge of the carrier content could be the most prominent reason for ESP students' speaking anxiety. Also, the results of MANOVA show that the item with the most marked difference is "Students think that the lack of the knowledge of their academic discipline is preventing them from speaking English for specific purposes" (item 4). The study identified 17 reasons leading to speaking anxiety of ESP students. Among them, 13 were based on the foreign language speaking anxiety scale created by He (2013) and 4 on the findings on important reasons leading to students' business English speaking anxiety by Čepon (in press).

The evidence from previous research shows that negative coping strategies could be transformed into effective anxiety-coping strategies (Kao \& Craigie, 2013); therefore, ESP teachers should find creative ways to reinforce their students' existing effective coping behaviours and eliminate those that are maladaptive: primarily by creating an environment conducive to minimizing speaking anxiety, focusing on developing the necessary skills for coping with speaking anxiety and trying to customize their activities to the affective needs of the learners (Young, 1991). With a view to minimizing speaking anxiety, ESP teachers could more often discuss ESP topics that the students are familiar with or knowledgeable about in English and in their mother tongue, as well as prepare an ESP curriculum and learning materials based on the carrier content covered in other subjects in English and in Slovenian (Čepon, 2015). Another strategy to reduce cognitively mature ESP students' speaking anxiety could be promoting 
conversations about non-ESP topics (e.g. concerning the current state of affairs in the country, pop culture, etc.), as well as allowing sufficient time for answering and waiting for the students to speak until they have exhibited an eagerness to do so (Čepon, 2015; Krashen, 1982). The combined effect of insufficient carrier content and insufficient real content of ESP instruction, plus a lack of ESP vocabulary, is not just anxiety inducing, but may render some cognitively mature ESP students incapable of expressing themselves as young professionals, intellectuals and individuals (Čepon, 2015). Eventually, they may become almost "incapable of communicating their inability to communicate" in an ESP class (Granger, 2004).

According to He (2013), oral test anxiety may cause a negative performance in ESP, inhibit students from studying efficiently, and decrease their interest in ESP, therefore, teachers should include students' classroom performance in their semester assessment. Similarly, fear of oral tests appeared at the top of the teachers' lists in the study by He (2013) and in the middle of the students' list of the importance of reasons for speaking anxiety in ESP. A significant difference in this aspect - oral exam anxiety - suggests something important that can only be guessed at. All language teachers have witnessed the struggles of students during an oral exam, so it is not surprising that teachers rank it high. If the students do not rank it high, it could suggest that when they think about speaking anxiety, the feelings that last longer are emphasized. In other words, speaking anxiety before and during an oral test may be quite severe, but is ephemeral, while the threat of having to speak in English on any particular day is not so short-lived and transitory. Some of the anxiety-reducing strategies could include reminding ESP students that speaking in an ESP class is a vital part of FLL, not a test situation. In other words, the realization that speaking is but a means of achieving ESP knowledge, and not the ultimate goal of ESP classroom interaction, might have a calming effect on high-anxiety ESP students (Čepon, 2015).

Additionally, as an anxiety-reducing technique, ESP teachers should employ proactive focus on linguistic form (FoF) and avoid overcorrection ${ }^{2}$. Moreover, and instead of direct correction, they should use implicit unobtrusive exchanges in the form of immediate contingent auditory recasting (Doughty, 2003), as this appears to have little anxiety-evoking effect on ESP students (Čepon, 2015). ESP students claim they usually feel uncomfortable when being the focus of attention in ESP class, especially when they are not prepared enough and cannot speak accurately and consequently also not fluently. A strategy that is likely to decrease ESP students' speaking anxiety is not to put anxiety-prone students in the limelight before they are ready for an oral task, as well as providing a relaxed atmosphere

\footnotetext{
${ }^{2}$ Focus on form (FoF/FonF) is a type of FL/L2 instruction that is characterized by a brief, incidental instructional attention to linguistic features within a communicatively meaningful context, as opposed to the other two types: the type of instruction focusing solely on meaning and the type focusing solely on linguistic features (FormS/FonFS or a deliberate teacher-fronted discussion of grammatical forms in isolation in the classroom) (Doughty, 2001, 2003; Norris \& Ortega, 2000; Williams, 2005).
} 
where language errors are considered natural in the process of ESP learning, implementing group and project work, and focusing on fluency rather than accuracy (Čepon, 2015).

The results of the present study regarding ESP students' concern over a negative evaluation from the ESP teacher or their peers corroborated the findings of earlier studies (Horwitz et al., 1986). In other words, the concern about others' negative evaluation, avoidance of evaluative situations, and the fear and expectation that others would evaluate oneself negatively ranks high among the main reasons for speaking anxiety in ESP in our study. The strategies to minimize social pressures from a peer group should encompass a shift in attitude in order to make ESP students change the way they regard one another. In other words, using dialogue to substitute a competitive condition in an ESP class with a collaborative condition, as well as using reflection to place more focus on the group and on viewing peers as members of the same learning community (Čepon, 2015). Thus, teachers should create a supportive learning classroom community (Brophy, 2004; Dörnyei, 2001) as well as a learning community that provides "optimal motivation" (Alderman, 2004), and a "collaborative atmosphere" (Gregersen, 2003).

Despite the fact that our study showed that the knowledge of the carrier content was paramount for ESP students, the question arises as to how and when pre-experience ESP students should acquire in English and in their mother tongue the specialist subject content knowledge related to various academic disciplines. Based on the study, it is evident that ESP students experience speaking anxiety because they are not able to fully comprehend that, as an approach to FL teaching, ESP was meant to be different from general English instruction as it integrates discursive competence of a certain discipline/profession, disciplinary knowledge and professional practice. The acronym TENOR for "teaching English for no particular purpose" has not been coined for general English instruction in vain.

To explain why the lowest levels of consonance between ESP teachers' and students' points of view were reached on the issue of the importance of the carrier content for speaking anxiety in ESP, we probably should look at this question in the broader context of the ESP teacher's role in ESP instruction. In-depth interviews with ESP teachers (Čepon, in press) revealed that one of the answers could be the fact that ESP instruction does not presuppose that ESP teachers should be the "primary knowers" of the carrier content (Dudley-Evans \& St. John, 1998: 13). ESP teachers reportedly require three things only: a positive attitude towards ESP content, knowledge of the fundamental principles of the subject area, and an awareness of how much they probably already know, all of which can be summed up as "the ability to ask intelligent questions" (Hutchinson \& Waters, 1987: 163). Therefore, ESP teachers tend to assume that ESP learners have accepted more responsibility for their own learning of the real and carrier contents than they in fact have; thus ESP teachers feel they can focus on putting as much emphasis as possible on the real content of ESP instruction - ESP learners' general 
ability to communicate in an FL more effectively (Dudley-Evans \& St. John, 1998; Ellis \& Johnson, 1994; Hutchinson \& Waters, 1987; Johns \& Price-Machado, 2001).

Another possible explanation based on ESP teachers' claims (Čepon, 2015) for seemingly underestimating the impact of a lack of carrier content knowledge on the levels of ESP students' speaking anxiety is that ESP teachers are inclined to presume that the levels of the carrier content knowledge that ESP students should possess are substantially higher than in reality, both in their mother tongue and in English. In other words, the teachers' focus on their students mastering a communicative competence in English may sometimes prevent ESP teachers from realizing that pre-experience ESP learners are still in the process of acquiring the specialist subject content in their mother tongue. The fact that the latter is still theoretical and not internalized in L1 is the greatest obstacle to translating the knowledge of the subject matter from L1 into English that ESP teachers do not always comprehend fully. A third possible explanation is the disregard of ESP teachers of the impact of a lack of carrier content on elevated levels of ESP students' speaking anxiety, which is manifest in negative strategy of ignoring the physical manifestations of fear that a minority of ESP teachers use instead of taking greater interest in the students' perceptions of the reasons for their speaking anxiety (Čepon, 2015).

\section{CONCLUSIONS}

The study showed that ESP students and teachers hold different perspectives on the reasons for speaking anxiety. The students emphasized a lack of the knowledge of the carrier content, while the teachers gave priority to oral tests, failing to speak fluently and a concern about being looked down upon by their classmates/peers for making mistakes. In other words, a lack of the knowledge of the carrier content is an important reason for speaking anxiety that ESP teachers would benefit from being more aware of.

These findings are likely to provide insightful information and have implications for Slovenian (and broader regional) tertiary ESP education. The difference in perception of the reasons for speaking anxiety between ESP students and teachers calls for further mutual understanding with a view to becoming better informed of each other's perceptions. Pedagogically, the explicitness of the reasons for speaking anxiety and raising ESP students' awareness of the problem of speaking anxiety could provide the necessary foundation and training geared towards the alleviation of students' speaking anxiety in ESP (He, 2013). Teachers should continue to provide support to anxious students and strive for deeper insights into students' ways of coping with speaking anxiety. Without awareness of the causes of ESP speaking anxiety, teachers often tend to attribute students' reluctance to participate in speaking activities to a lack of motivation, while the real reason behind their reluctance is ignored. Therefore, one key problem to 
address to alleviate ESP students' speaking anxiety is their insufficient knowledge of the carrier content of a specific academic discipline, both in the students' mother tongue and English (Čepon, 2015).

Although this study investigated the teachers' and students' perceptions of the reasons for ESP speaking anxiety in 18 higher educational institutions in Slovenia and found valuable insights into the reasons for this multidimensional phenomenon, its findings are difficult to generalize to ESP students at large. Additional methods, such as participant observation, could be used to identify the extent to which the specifics of ESP instruction induce the speaking anxiety of a target group of ESP students.

[Paper submitted 12 Jun 2016]

[Revised version received 26 Aug 2016]

[Revised version accepted for publication 3 Oct 2016]

\section{References}

Alderman, M. K. (2004). Motivation for achievement. Mahwah NJ: Lawrence Erlbaum.

Boyce, J. S., Alber-Morgan, S. R., \& Riley, J. G. (2007). Fearless public speaking. Childhood Education, 83(1), 1-11. doi: 10.1080/00094056.2007.10522899

Brophy, J. (2004). Motivating students to learn. New Jersey: Lawrence Erlbaum Associates.

Çagatay, S. (2015). Examining EFL students' foreign language speaking anxiety: The case at a Turkish state university. Procedia - Social and Behavioural Sciences, 199(6), 648-656.

Čepon, S. (2012). Higher education institutions without foreign language continuity. English Language Teaching, 5(8), 31-41.

Čepon, S. (2015). Coping strategies for reducing English language speaking anxiety in the Balkans. Didactica Slovenica, 30(3/4), 50-62.

Čepon, S. (in press). Causes of business English speaking anxiety in the Balkans. Journal of English Studies, 14(1).

Dörnyei, Z. (2001). Motivational strategies in the language classroom. Cambridge: Cambridge University Press.

Dörnyei, Z. (2005). The psychology of the language learner, individual difference in second language acquisition. New Jersey: Lawrence Erlbaum and Associates.

Doughty, C. J. (2001). Cognitive underpinings of focus on form. In P. Robinson (Ed.), Cognition and second language instruction (pp. 206-258). Cambridge: Cambridge University Press.

Doughty, C. J. (2003). Instructed SLA: Constraints, compensation, and enhancement. In C. J. Doughty, \& M. H. Long (Eds.), The handbook of second language acquisition (pp. 256310). Oxford: Blackwell.

Dudley-Evans T., \& St. John, M. J. (1998). Developments in English for specific purposes. Cambridge: Cambridge University Press.

Ellis, M., \& Johnson, C. (1994). Teaching business English. Oxford: Oxford University Press.

Fish, L. J. (1988). Why multivariate methods are usually vital. Measurement and evaluation in counseling and development, 21(2), 130-137. 
Gatehouse, K. (2001). Key issues in English for specific purposes (ESP) curriculum development. The Internet TESL Journal, 7(10). Retrieved from http://iteslj.org/Articles/Gatehouse-ESP.html

Granger, C. A. (2004). Silence in second language learning. Clevedon, UK: Multilingual Matters LTD.

Gregersen, T. S. (2003). To err is human: A reminder to teachers of language-anxious students. Foreign Language Annals, 36(1), 25-32. doi: 10.1111/j.19449720.2003.tb01929.x

Grognet, G. A. (1997). Integrating employment skills in adult ESL instruction. Center for Applied Linguistics. Project in Adult Immigrant Education (PAIE). Retrieved from http://www.cal.org/caela/esl_resources/digests/EskilsQA.html

He, D. (2013). What makes learners anxious while speaking English: A comparative study of the perceptions held by university students and teachers in China. Education Studies, 39(3), 338-350. doi: 10.1080/03055698.2013.764819

Heng, C. S., Abdullah, A. N., \& Yosaf, N. B. (2012). Investigating the construct of anxiety in relation to speaking skills among ESL tertiary learners. 3L: The Southeast Asian Journal of English Language Studies, 18(3), 155-166.

Horwitz, E. K. (2001). Language anxiety and achievement. Annual Review of Applied Linguistic, 21(2), 112-126.

Horwitz, E. K., Horwitz, M. B., \& Cope, J. (1986). Foreign language classroom anxiety. The Modern Language Journal, 70(2), 125-132.

Horwitz, E. K., Horwitz, M. B., \& Cope, J. (1991). Foreign language classroom anxiety. In E. K. Horwitz, \& D. J. Young (Eds.), Language anxiety: From theory and research to classroom implications (pp. 27-36). New Jersey: Prentice Hall.

Hutchinson, T., \& Waters, A. (1987). English for specific purposes: A learning-centred approach. Cambridge: Cambridge University Press.

Hyland, K. (2002). Specificity revisited: How far should we go now? English for Specific Purposes, 21(4), 385-395. doi: 10.1016/S0889-4906(01)00028-X

Hyland, K. (2008). As can be seen: Lexical bundles and disciplinary variation. English for Specific Purposes, 27(1), 4-21. doi:10.1016/j.esp.2007.06.001

Johns, A. M. \& Price-Machado, D. (2001). English for specific purposes: Tailoring courses to students needs and to the outside world. In M. Celce-Murcia (Ed.), Teaching English as a Second or Foreign Language (pp. 29-43). Boston, Mass.: Heinle \& Heinle.

Johnson, A. (2016). English becomes Esperanto. The Economist. Retrieved from http://www.economist.com/news/books-and-arts/21697210-institutionseuropean-union-will-still-speak-kind-english-if-britain

Kao, P. O., \& Craigie, P. (2013). Coping strategies of Taiwanese university students as predictors of English language learning anxiety. Social Behaviour and Personality, 4(3), 411-420. doi: 10.2224/sbp.2013.41.3.411

Koch, A. S., \& Terrell, T. D. (1991). Affective reactions of foreign language students to natural approach activities and teaching procedures. In E. K. Horwitz, \& D. J. Young (Eds.), Language anxiety: From theory and research to classroom implications (pp. 109-125). London: Prentice Hall International.

Krashen, S. (1982). Principles and practice in second language acquisition. Oxford: Pergamon Press.

MacIntyre, P. D., \& Gardner, R. C. (1994). The subtle effects of language anxiety on cognitive processing in the second language. Language Learning, 44(3), 283-305. doi: 10.1111/j.1467-1770.1994.tb01103.x 
Norris, J. M., \& Ortega, L. (2000). Effectiveness of L2 instruction: A research synthesis and uantitative meta-analysis. Language Learning, 50(3), 417-528.

Öztürk, G., \& Gürbüz, N. (2014). Speaking anxiety among Turkish EFL learners. Journal of Language and Linguistic Studies, 10(1), 1-17.

Price, M. L. (1991). The subjective experience of foreign language anxiety. In E. K. Horwitz, \& D. J. Young (Eds.), Language anxiety: From theory and research to classroom implications (pp. 101-108). New Jersey: Prentice Hall.

Subaşı, G. (2010). What are the main sources of Turkish EFL students' anxiety in oral practice? Turkish Online Journal of Qualitative Inquiry, 1(2), 29-49.

Widdowson, H. G. (1984). Learning purpose and language use. Oxford: Oxford University Press.

Williams, J. (2005). Form-focused instruction. In E. Hinkel (Ed.), Handbook of research in second language teaching and learning (pp. 671-691). Mahwah, NJ: Lawrence Erlbaum.

Wu, C. P., \& Lin, H. J. (2014). Anxiety about speaking a foreign language as a mediator of the relation between motivation and willingness to communicate. Perceptual and Motor Skills, 119(3), 785-798. doi: 10.2466/22.PMS.119c32z7

Yan Xiu, J., \& Horwitz, K. E. (2008). Learners' perceptions of how anxiety interacts with personal and instructional factors to influence their achievement in English. Language Learning, 58(1), 151-183. doi: 10.1111/j.1467-9922.2007.00437.x

Young, D. J. (1990). An investigation of students' perspectives on anxiety and speaking. Foreign Language Annals, 23(6), 539-553.

Young, D. J. (1991). Creating a low-anxiety classroom environment: What does language anxiety research suggest? The Modern Language Journal, 75(4), 426-439.

Zhang, R., \& Zhong, J. (2012). The hindrance of doubt: Cause of language anxiety. International Journal of English Linguistics, 2(3), 27-33. doi: http://dx.doi.org/10.5539/ijel.v2n3p27

Zientek, L. R., \& Thompson, B. (2009). Matrix summaries improve research reports: Secondary analyses using published literature. Educational Researcher, 38, 343-352. doi: 10.3102/0013189X09339056

Zhu, W. (2008). On differences between General English teaching and BE teaching. English Language Teaching, 1(2), 90-95. doi: http://dx.doi.org/10.5539/elt.v1n2p90

SLAVICA ČEPON is Assistant Professor at the Faculty of Economics, University of Ljubljana (Slovenia), where she teaches business English. Her specific professional interests include ESP textbook evaluation, foreign language learners' needs analysis, general English attrition, the benefits of IT for business English and the interface between general and business English instruction. Her current research focuses on fear of failure and English language anxiety. 